\title{
Optimalisasi Distribusi Armada Transportasi UKM Tahu Mojosongo - Solo
}

\author{
Edwin Fakhrul Arifin $^{1)}$, Febriana Kusumawardani ${ }^{2)}$, Poppy Nandasari ${ }^{3)}$, Yuniaristanto ${ }^{4)}$ \\ ${ }^{1234)}$ Teknik Industri, Program Studi Sarjana Teknik Industri, Universitas Sebelas Maret \\ J1. Ir. Sutami 36A, Surakarta 57126, Indonesia \\ Telp. 0271-6322110
}

\begin{abstract}
A company or business entity is required to perform the activities effectively and efficiently. The economic condition of the enterprise develop rapidly between companies or business entities get stiff competition. In the face of competition, companies need planning and cost control, especially in distribution transport logistics. One way that can do is to reduce operating costs, especially in terms of logistic distribution, logistic distribution costs which are rarely considered. The study was conducted at the home industry manufacturing know Sentra Industry Tahu, Mojosongo RW 03, Surakarta. The problem that occurs is unoptimalization product distribution that due to limited fleet which causes inefficient distribution activities in terms of time and cost. Of the issues raised, there are vehicles used alternative is to use motorcycles and cars, both for new vehicles and used vehicles. To find an alternative use can be done by calculating the net persent value and payback period. Based on the calculation of NPV and PBP is known that the chosen alternative is to increase the company's investment in the form of the addition of used cars as a consistent supporter of logistic distribution with the NPV was Rp. 426.548.000,00 and the return on investment amounted was for 3 months 17 days.
\end{abstract}

Keywords: Investment feasibility, logistic system, net present value, payback period, transportation

\section{Pendahuluan}

Suatu perusahaan atau badan usaha dituntut untuk melakukan kegiatan secara efektif dan efisien. Kondisi perekonomian badan usaha berkembang cepat sehingga antar perusahaan atau badan usaha mendapatkan persaingan yang ketat. Dalam menghadapi persaingan, perusahaan perlu perencanaan dan pengendalian biaya terutama pada distribusi logistik transportasi, dengan cara mengurangi biaya operasional, perusahaan mendapatkan keuntungan yang lebih besar (Kristanto \& Suryani, 2015). Seringkali, biaya distribusi tidak terlalu diperhatikan padahal seharusnya permasalahan sistem transportasi logistik nasional seperti biaya dan efisiensi menjadi perhatian utama (Utami, 2015). Efek yang ditimbulkan dari biaya distribusi ini sangat besar karena memakan biaya yang tidak sedikit. Oleh karena itu perlu dilakukan penerapan sistem logistik yang baik dalam melaksanakan aktivitas perusahaan.

Menurut Chandra (2013), transportasi adalah pemindahan manusia atau barang dari satu tempat ke tempat lainnya dengan menggunakan sebuah wahana yang digerakkan manusia atau mesin. Transportasi merepresentasikan elemen yang paling penting dalam biaya logistik dalam perusahaan (Ballou, 2004). Menurut Nasution dalam Chandra (2013) terdapat unsur-unsur transportasi yang terdiri atas ada uatan yang diangkut, tersedia kendaraan sebagai alat angkutnya, ada jalanan yang dapat dilalui, ada terminal asal dan terminal tujuan, serta sumber daya manusia dan organisasi atau manajemen yang menggerakkan kegiatan transportasi tersebut.

Di dalam industri, sistem penjadwalan dan pengelolaan rute distribusi memiliki peranan penting bagi perusahaan, oleh karenanya menyadari bahwa logistik mempunyai peranan yang sangat penting terhadap biaya dan keputusan mengenai logistik dan penentuan rute jalur distribusi logistik (Kristanto \& Suryani, 2015). Logistik menurut Council of Supply Chain

*Correspondance: edwinfakhrul@gmail.com 
Management Professionals dalam Chandra (2013) adalah bagian dari manajemen rantai pasok (supply chain) dalam perencanaan, pengimplementasian, dan pengontrolan aliran dan penyimpanan barang, informasi, dan pelayanan yang efektif dan efisien dari titik asal ke titik tujuan sesuai dengan permintaan konsumen. Menurut Lambert D.M., et. al, dalam Chandra (2013) untuk mengalirkan barang dari titik asal menuju titik tujuan akan membutuhkan beberapa aktivitas yang dikenal dengan 'aktivitas kunci dalam logistik' diantaranya: 1)customer service, 2) demand forecasting/planning, 3) inventory management, 4) logistics communications, 5) material handling, 6) traffic and transportation, dan 7) warehousing and storage.

Penelitian ini menitikberatkan pada salah satu aktivitas kunci dari sistem logistik yaitu transportasi. Objek yang digunakan sebagai bahan penelitian adalah transportasi atau armada distribusi di home industry pembuatan tahu. Observasi ini dilakukan di Sentra Industri Tahu Kelurahan Mojosongo RW 03, Surakarta. Di lokasi tersebut terdapat kurang lebih 30 industri rumahan yang memproduksi tahu dan tempe. Industri yang dipilih adalah industri milik Bapak Acok Warso P yang memproduksi khusus produk tahu. Dengan jumlah karyawan adalah 15 orang.

Permasalah utama yang terjadi yaitu ketidakoptimalan armada distribusi akibat keterbatasan kapasitas armada yang menyebabkan kegiatan distribusi tidak efisien dari segi waktu maupun biaya. Dalam segi waktu kegiatan distribusi yang dilakukan memakan waktu yang lama dan dari segi biaya kegiatan distribusi memerlukan biaya yang besar (misalnya bahan bakar) yang banyak akibat kegiatan dilakukan bolak-balik secara terus menerus. Oleh karena itu, perlu adanya pertimbangan dilakukannya investasi untuk mengadakan moda transportasi yang lebih sesuai baik dari segi kapasitas, waktu, dan biaya operasional yang dibutuhkan. Menurut Suad dan Suwarsono (2008:16), investasi adalah untuk memaksimumkan nilai pasar dan modal sendiri. Pemilik modal sendiri adalah perusahaan-perusahaan seharusnya berusaha meningkatkan kemakmuran mereka. Maka perlu adanya analisis kelayakan investasi dari moda transportasi yang diusulkan dan sebagai dasar keputusan dalam memilih dari alternatif-alternatif yang ada. Oleh karena itu pada penelitian ini bertujuan untuk melakukan perbandingan dan analisis kelayakan investasi dalam menyelesaikan permasalahan ketidakoptimalan perusahaan dalam melakukan kegiatan distribusi produk sesuai dengan sumberdaya dan kemampuan yang dimiliki perusahaan sehingga aktivitas transportasi yang dilakukan dapat lebih efisien dalam segi waktu maupun biaya.

\section{Tinjauan Pustaka}

Studi kelayakan merupakan pengkajian yang bersifat menyeluruh dan menyoroti segala aspek kelayakan investasi, sehingga dapat menyuguhkan hasil analisis secara kuantitatif tentang manfaat yang diperoleh dibandingkan dengan sumber daya yang diperlukan (Soeharto, 2002). Kelayakan artinya penelitian yang tersebut dilakukan untuk menentukan apakah usaha yang dijalankan akan memberikan manfaat yang lebih besar dibandingkan dengan biaya yang dikeluarkan.

Soeharto (2002) menjelaskan bahwa pengkajian kelayakan atas suatu usulan proyek bertujuan untuk mempelajari usulan dari segala segi secara profesional agar setelah usulan proyek tersebut diterima dan dilaksanakan, benar-benar dapat mencapai hasil sesuai dengan yang direncanakan, jangan sampai terjadi setelah proyek selesai dibangun dan dilaksanakan, ternyata hasilnya jauh dari harapan. Dengan ini, dapat disimpulkan bahwa tujuan dari studi kelayakan proyek adalah untuk menghindari keterlanjuran penanaman modal sebelum proyek direalisasikan.

Menurut Soeharto (2002) kerangka format studi kelayakan proyek pembangunan atau proyek industri adalah sebagai berikut: 
a. Menentukan berapa lama umur unit usaha hasil proyek.

b. Menentukan ruang lingkup proyek, seperti kapasitas instalasi, pemilihan teknologi produksi, peralatan, material, fasilitas pendukung (perumahan pegawai, pelabuhan), dan lain-lain.

c. Membuat perkiraan kurun waktu serta jadwal pelaksanaan investasi.

d. Membuat perkiraan biaya awal dan ongkos produksi.

e. Melakukan analisis finansial dan ekonomi terhadap rencana investasi.

f. Menetapkan jenis dan sumber dana.

g. Membuat kesimpulan menarik tidaknya proyek tersebut untuk direalisasikan.

Beberapa metode yang digunakan perhitungan analisis kelayakan investasi yang digunakan dalam penelitian ini adalah :

1. Net Present Value

Metode Net Present Value merupakan metode yang dilakukan dengan cara membandingkan nilai sekarang dari aliran kas masuk bersih (proceeds) dengan nilai sekarang dari biaya pengeluaran suatu investasi (outlays).

2. Payback period

Perhitungan payback period, dipengaruhi oleh cashflow. Dimana cash flow adalah tata aliran uang masuk dan keluar per periode waktu pada suatu perusahaan (Giatman, 2011). Cash flow terdiri dari:

a. Cash-in (uang masuk), umumnya berasal dari penjualan produk atau manfaat terukur (benefit).

b. Cash-out (uang keluar), merupakan kumulatif dari biaya-biaya (cost) yang dikeluarkan.

Cash flow yang dibicarakan dalam ekonomi teknik adalah cash flow investasi yang bersifat estimasi/prediktif. Karena kegiatan evaluasi investasi pada umumnya dilakukan estimasi atau perkiraan terhadap cash flow yang akan terjadi apabila rencana investasi tersebut dilaksanakan. Dalam suatu investasi secara umum, cash flow akan terdiri dari empat komponen utama, yaitu:

a. Investasi

b. Operational cost

c. Maintenance cost

d. Benefit / manfaat

Secara umum bentuk grafis dari cash flow suatu investasi tersebut diperlihatkan pada gambar

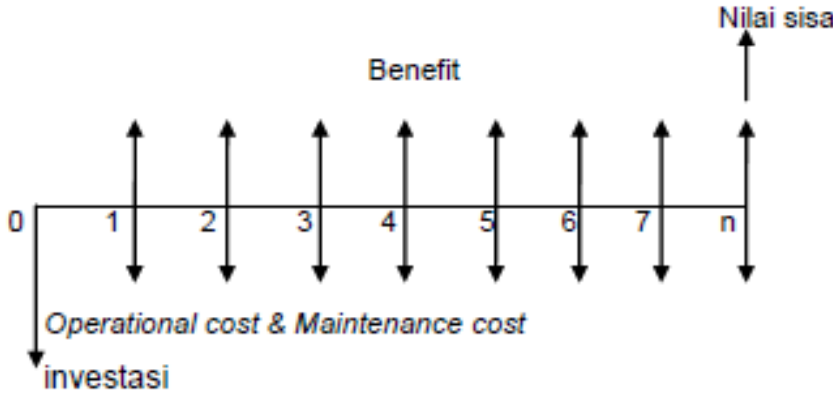

Gambar 1. Cash flow 


\section{Metodologi Penelitian}

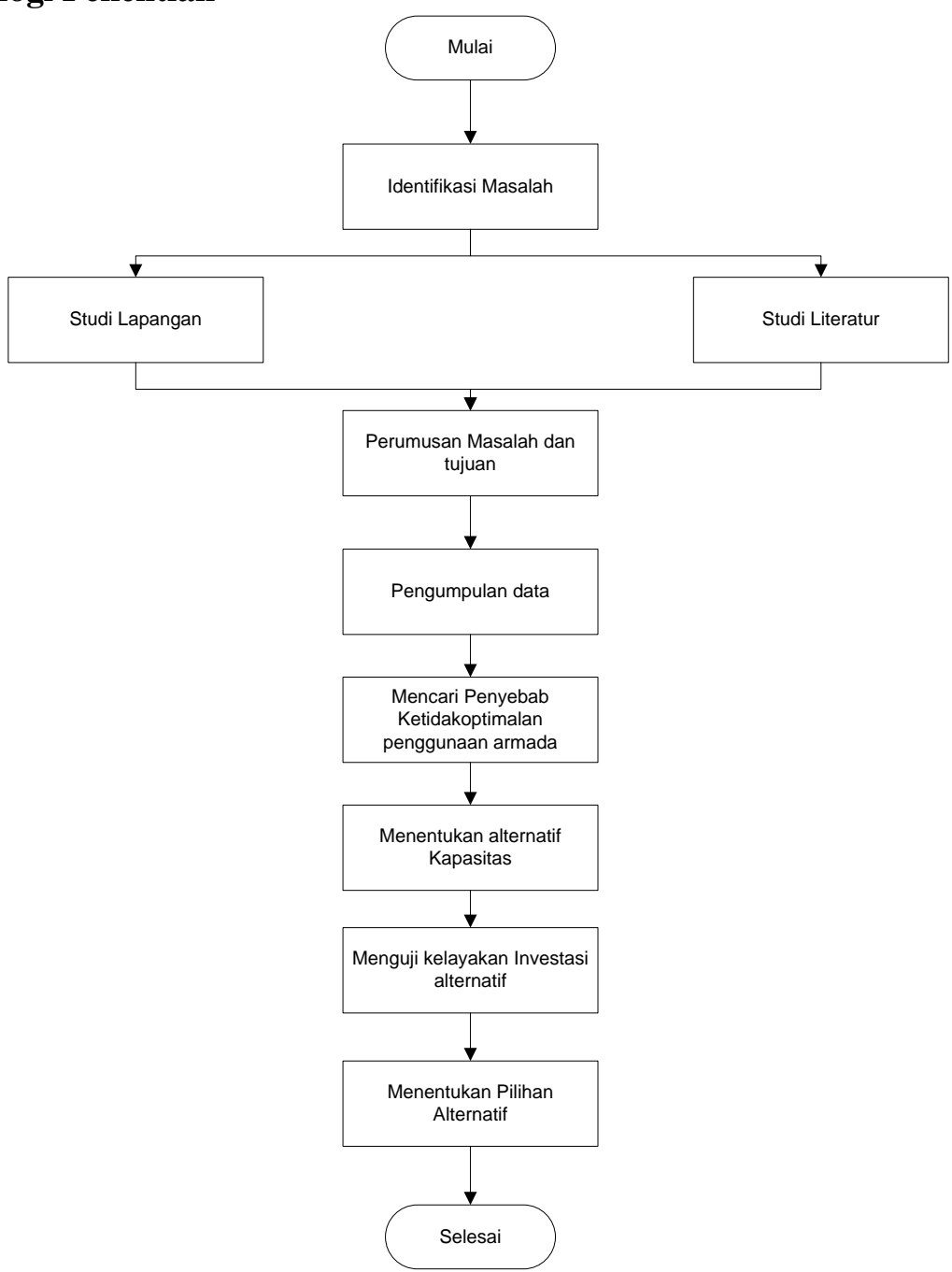

Gambar 2. Metodologi penelitian

Metodologi penelitian yang dipakai selama melakukan penelitian Sistem Logistik mengenai Transportasi di UKM Tahu Mojosongo. Metode penelitian ini terdiri dari beberapa tahapan, yaitu tahap pendahuluan, pengumpulan data, pengolahan dan data, dan kesimpulan.

Tahap pendahuluan merupakan tahapan awal melakukan penelitian, tahapan didahului dengan menetapkan maksud dan tujuan awal melakukan penelitian. Maksud dan tujuan melakukan penelitian ini adalah untuk mengetahui dan menetapkan alternatif solusi yang layak untuk permasalahan yang ada di perusahaan tersebut. Setelah menetapkan maksud dan tujuan kemudian menetapkan perusahaan yang diteliti, dalam hal ini menetapkan UKM Tahu Mojosongo sebagai tempat melakukan penelitian. Tahap selanjutnya adalah merumuskan masalah yang ada di UKM Tahu Mojosongo dan membuat Alternatif solusi untuk masalah tersebut. Masalah yang dikaji adalah moda transportasi barang dan volume komoditas yang akan diangkut, serta lamanya waktu pendistribusian dari ke pasar ke pasar tradisional. Setelah topik permasalahan di dapat kemudian tahapan selanjutya adalah tahap membuat administrasi dan perijinan ke perusahaan.

Tahap selanjutnya adalah tahapan identifikasi masalah dan pengumpulan data. Identifikasi masalah dilakukan dengan cara menjabarkan masalah dengan menggunakan fishbone diagram, selanjutnya dilakukan pengumpulan data dengan cara melakukan observasi langsung ke UKM Tahu Mojosongo. Data perusahaan diperoleh dengan melakukan wawancara 
secara langsung pada pemilik dan karyawan yang bekerja di UKM Tahu Mojosongo. Dengan melakukan wawancara tersebut maka diperoleh data profil perusahaan dan moda transportasi yang berada di UKM Tahu Mojosongo.

Tahapan selanjutnya adalah tahap pengolahan data. Data yang diperoleh dari hasil observasi dan wawancara kemudian dihitung dan diolah dengan menggunakan perhitungan NPV dan payback periode untuk mengetahui alternatif solusi mana yang menjadi alternatif solusi terbaik untuk dijadikan solusi dalam menyelesaikan permasalahan di UKM Tahu Mojosongo.

Setelah melakukan perhitungan NPV dan payback periode kemudian dilakukan analisis mengenai alternatif mana yang akan dipilih sebagai alternatif terbaik. Pemilihan didasarkan pada nilai NPV yang paling besar berdasarkan perhitungan, sedangkan payback periode dipilih berdasarkan nilai yang paling kecil. Setelah alternatif terbaik terpilih kemudian disimpulkan mengenai hasil dari penelitian di UKM Tahu Mojosongo mengenai solusi alternatif terbaik yang dipilih.

\section{Hasil dan Pembahasan}

4.1 Identifikasi Masalah

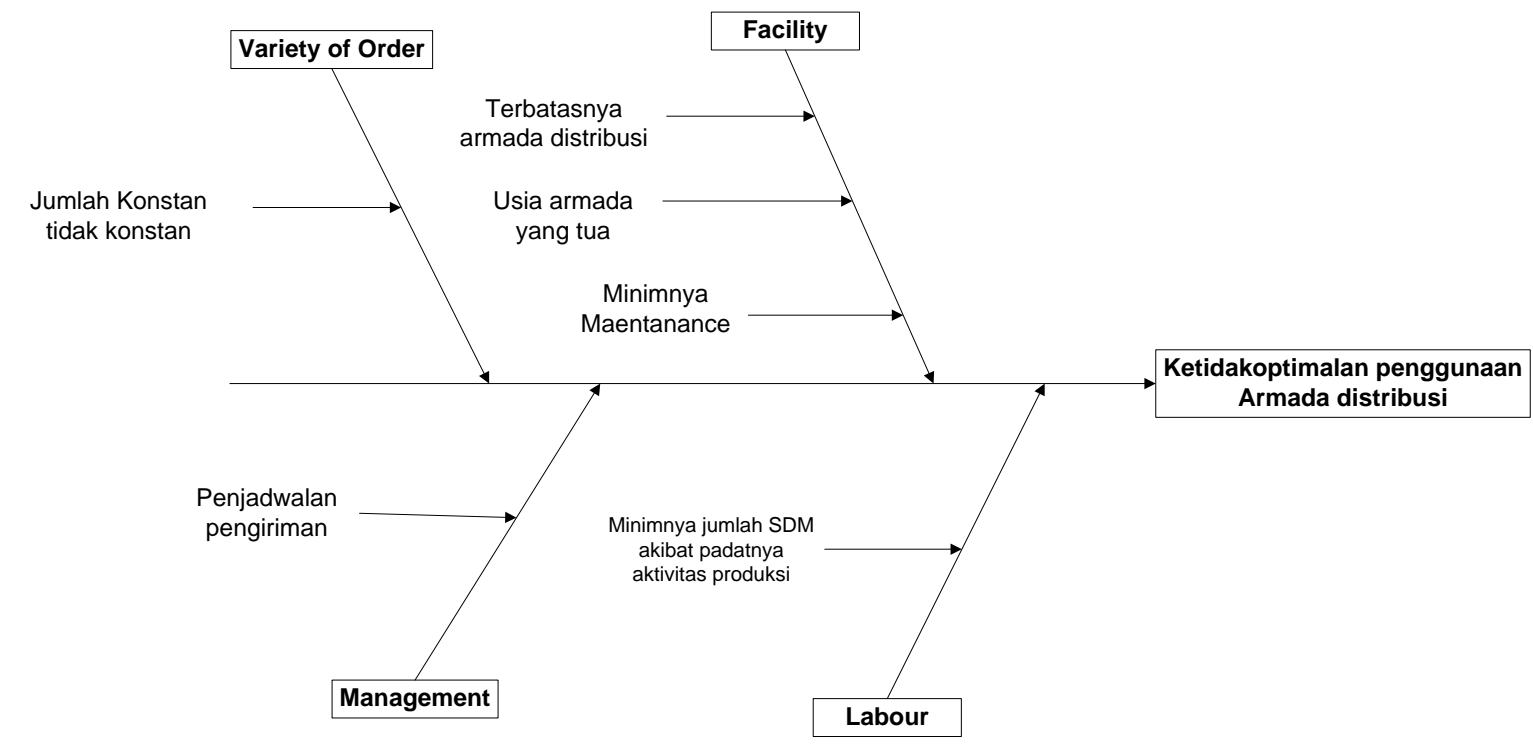

Gambar 3. Fishbone Diagram ketoidakoptimalan penggunaan armada distribusi

Berdasarkan hasil identifikasi masalah diketahui bahwa terdapat lima faktor penyebab terjadinya ketidakoptimalan penggunaan armada distribusi produk yaitu akibat Man, Variety of order, management, dan facility. Dari keempat factor tersebut facility merupakan factor yang paling signifikan yang menyebabkan masalah tersebut yaitu karena keterbatasan jumlah dan kapasitas armada, usia armada dan tingkat maintenance yang rendah. Oleh karena itu facility merupakan factor yang akan dibahas dalam penelitian ini.

\subsection{Uji Kelayakan Investasi Moda Transportasi baru}

Berdasarkan hasil diatas permasalahan yang ada dalam UKM Tahu Mojosongo ialah ketidakefektifan proses distribusi akibat fasilitas yang dimiliki UKM tersebut, dimana dalam proses pendistribusian produk, perusahaan masih menggunakan moda transportasi sepeda motor. Jumlah sepeda motor yang dimiliki pun juga terbatas, perusahaan hanya memiliki satu buah sepeda motor. Dimana untuk mendistribusikan tahu tersebut ke pasar - pasar di 
Surakarta, proses distribusi dilakukan dengan bolak balik, karena kapasitas angkut sepeda motor yang sedikit yaitu hanya 3 ember saja.

Maka dari itu untuk menyelesaikan masalah diusulkan solusi berupa penggantian armada sepeda motor yang dimiliki perusahaan dengan moda transportasi dengan kapasitas angkut yang lebih besar yaitu mobil bak, dengan kapasitas angkut adalah 16 ember. Dalam perhitungan analisis kelayakan investasi ini ditentukan dua alternatif pengadaan mobil bak tersebut. Alternatif pertama adalah membeli mobil bak baru dan alternatif kedua adalah membeli mobil bak bekas.

Setelah mengetahui spesifikasi dari kedua alternatif tersebut, kemudian melakukan analisis kelayakan investasi. Dalam penelitian ini digunakan dua jenis metode analisis investasi, yaitu metode Net Present Value dan Pay Back Periode. Berikut ini adalah perhitungan analisis kelayakan investasi UKM Tahu Mojosongo, yaitu:

\section{a. Metode NPV}

Tabel 1. NPV alternatif beli mobil baru

\begin{tabular}{|c|c|c|c|c|c|c|c|c|}
\hline Tahun & Investasi & Biaya Operasional & Maintenance & Total Biaya & Pendapatan & Benefit & discount factor (10\%) & npv \\
\hline 0 & Rp $109,760,000.00$ & & & & & & & $\operatorname{Rp}(109,760,000.00)$ \\
\hline 1 & & $\operatorname{Rp} 1,583,964,000.00$ & Rp 22,254,000.00 & $\operatorname{Rp} 1,606,218,000.00$ & Rp $1,800,000,000.00$ & Rp 193,782,000.00 & 1.1 & Rp $176,165,454.55$ \\
\hline 2 & & Rp 1,583,964,000.00 & Rp 22,254,000.00 & $\operatorname{Rp} 1,606,218,000.00$ & Rp 1,800,000,000.00 & Rp 193,782,000.00 & 1.21 & Rp $160,150,413.22$ \\
\hline 3 & & $\operatorname{Rp} 1,583,964,000.00$ & $\operatorname{Rp~22,254,000.00}$ & $\operatorname{Rp} 1,606,218,000.00$ & Rp 1,800,000,000.00 & Rp 193,782,000.00 & 1.331 & Rp $145,591,284.75$ \\
\hline \multicolumn{8}{|c|}{ NPV } & Rp $372,147,152.52$ \\
\hline
\end{tabular}

Tabel 2. NPV alternatif beli mobil bekas

\begin{tabular}{|c|c|c|c|c|c|c|c|c|c|}
\hline Tahun & & Investasi & Biaya Operasional & Maintenance & Total Biaya & Pendapatan & Benefit & discount factor (10\%) & \\
\hline 0 & $\mathrm{Rp}$ & $58,000,000.00$ & & & $58,000,000.00$ & & & & $\operatorname{Rp}(58,000,000.00)$ \\
\hline 1 & & & Rp 1,583,964,000.00 & $\operatorname{Rp} 21,192,000.00$ & Rp 1,605,156,000.00 & Rp $1,800,000,000.00$ & Rp 194,844,000.00 & 1.1 & Rp 177,130,909.09 \\
\hline 2 & & & $\operatorname{Rp} 1,583,964,000.00$ & Rp 21,192,000.00 & $\operatorname{Rp} 1,605,156,000.00$ & Rp $1,800,000,000.00$ & Rp 194,844,000.00 & 1.21 & Rp $161,028,099.17$ \\
\hline 3 & & & $\operatorname{Rp~} 1,583,964,000.00$ & Rp 21,192,000.00 & Rp $1,605,156,000.00$ & Rp $1,800,000,000.00$ & Rp 194,844,000.00 & 1.331 & Rp $146,389,181.07$ \\
\hline \multicolumn{9}{|c|}{ NPV } & Rp $426,548,189.33$ \\
\hline
\end{tabular}

Tabel 3. NPV alternatif beli motor bekas

\begin{tabular}{|c|c|c|c|c|c|c|c|c|c|}
\hline Tahun & & Investasi & Biaya Operasional & Maintenance & Total Biaya & Pendapatan & Benefit & $\begin{array}{c}\text { discount } \\
\text { factor }(10 \%)\end{array}$ & \\
\hline 0 & $\mathrm{Rp}$ & $50.000 .000,00$ & & & $50.000 .000,00$ & & & & \begin{tabular}{|ll}
$R p$ & $(50.000 .000,00)$ \\
\end{tabular} \\
\hline 1 & & & \begin{tabular}{|ll}
$\operatorname{Rp}$ & $1.634 .364 .000,00$
\end{tabular} & Rp $33.390 .000,00$ & $\operatorname{Rp} 1.667 .754 .000,00$ & Rp $1.800 .000 .000,00$ & Rp $132.246 .000,00$ & 1,1 & $\begin{array}{ll}\mathrm{Rp} & 120.223 .636,36 \\
\end{array}$ \\
\hline 2 & & & Rp 1.634.364.000,00 & Rp 33.390.000,00 & Rp $1.667 .754 .000,00$ & Rp $1.800 .000 .000,00$ & Rp $132.246 .000,00$ & 1,21 & $\begin{array}{ll}\mathrm{Rp} & 109.294 .214,88\end{array}$ \\
\hline 3 & & & Rp 1.634.364.000,00 & Rp 33.390.000,00 & Rp $1.667 .754 .000,00$ & Rp $1.800 .000 .000,00$ & Rp 132.246.000,00 & 1,331 & $\begin{array}{ll}\mathrm{Rp} & 99.358 .377,16 \\
\end{array}$ \\
\hline \multicolumn{9}{|c|}{ NPV } & $\begin{array}{|ll|}\text { Rp } & 278.876 .228,40 \\
\end{array}$ \\
\hline
\end{tabular}

Dari data estimasi aliran kas untuk alternatif beli baru dan beli bekas tersebut, nantinya dapat dihitung Net Present Value dengan asumsi besarnya nilai MARR adalah sebesar $10 \%$.

Metode yang digunakan untuk analisis kelayakan investasi yang digunakan untuk memilih alternatif yang ingin diinvestasikan adalah metode Net Present Value (NPV), dimana NPV merupakan akumulasi dari semua penerimaan bersih (netto) selama umur investasi, dalam hal ini adalah tiga tahun. Berdasarkan metode NPV, suatu alternatif dikatakan layak jika NPV lebih dari 0. Sedangkan untuk alternatif yang dipilih merupakan alternatif yang memiliki NPV yang paling besar.

Untuk perhitungan dengan menggunakan metode Net Present Value (NPV), faktor yang mempengaruhi adalah estimasi aliran kas, MARR, dan tahun. Dari perhitungan yang dilakukan diperoleh total NPV untuk alternatif beli mobil baru adalah Rp 372.147.152,00, sedangkan untuk total NPV untuk alternatif beli mobil bekas adalah sebesar Rp 426.548.189,00, sedangkan untuk total NPV untuk alternatif beli motor bekas adalah sebesar Rp 278.876.228,40. 
Berdasarkan perhitungan diketahui bahwa nilai NPV yang terbesar adalah alternatif beli mobil bekas. Hasil perhitungan tersebut menunjukkan bahwa untuk periode tiga tahun, alternatif yang memperoleh pendapatan terbesar adalah alternatif membeli mobil bekas.

\section{b. Metode Payback period}

Tabel 4. Payback period alternatif beli mobil baru

\begin{tabular}{|c|c|c|c|c|c|c|c|c|c|c|c|c|c|}
\hline \multirow{2}{*}{$\begin{array}{c}\text { Tahun } \\
0\end{array}$} & \multicolumn{2}{|r|}{ Investasi } & \multirow{2}{*}{ Biaya Operasional } & \multicolumn{2}{|r|}{ Maintenance } & \multicolumn{2}{|r|}{ Total Biaya } & \multicolumn{2}{|r|}{ Pendapatan } & \multicolumn{2}{|r|}{ benefit } & \multicolumn{2}{|c|}{ Arus Kas Masuk } \\
\hline & $\mathrm{Rp}$ & $109,760,000.00$ & & & & & $109,760,000.00$ & & & & & & $(109,760,000.00)$ \\
\hline 1 & & & Rp $1,583,964,000.00$ & $\mathrm{Rp}$ & $22,254,000.00$ & $\mathrm{Rp}$ & $1,606,218,000.00$ & $\mathrm{Rp}$ & $1,800,000,000.00$ & $\mathrm{Rp}$ & $193,782,000.00$ & $\mathrm{Rp}$ & $84,022,000.00$ \\
\hline 2 & & & Rp $1,583,964,000.00$ & $\mathrm{Rp}$ & $22,254,000.00$ & $\mathrm{Rp}$ & $1,606,218,000.00$ & $\mathrm{Rp}$ & $1,800,000,000.00$ & $\mathrm{Rp}$ & $193,782,000.00$ & $\mathrm{Rp}$ & $277,804,000.00$ \\
\hline 3 & & & \begin{tabular}{|l|l|}
$\operatorname{Rp} 1,583,964,000.00$ \\
\end{tabular} & $\mathrm{Rp}$ & $22,254,000.00$ & $\mathrm{Rp}$ & $1,606,218,000.00$ & $\mathrm{Rp}$ & $1,800,000,000.00$ & $\mathrm{Rp}$ & $193,782,000.00$ & $\mathrm{Rp}$ & $471,586,000.00$ \\
\hline \multirow{2}{*}{$\mathrm{PPB}=$} & & 0.57 & tahun & & & & & & & & & & \\
\hline & & 6.796916122 & bulan & & bulan 24 hari & & & & & & & & \\
\hline
\end{tabular}

Tabel 6. Payback period alternatif beli mobil bekas

\begin{tabular}{|c|c|c|c|c|c|c|c|c|c|c|c|c|}
\hline Tahun & Investasi & Biaya Operasional & & Maintenance & & Total Biaya & & Pendapatan & & benefit & & us Kas Masuk \\
\hline 0 & $58,000,000.00$ & & & & $\mathrm{Rp}$ & $58,000,000.00$ & & & & & & $(58,000,000.00)$ \\
\hline 1 & & Rp $1,583,964,000.00$ & $\mathrm{Rp}$ & $21,192,000.00$ & $\mathrm{Rp}$ & $1,605,156,000.00$ & $\mathrm{Rp}$ & $1,800,000,000.00$ & $\mathrm{Rp}$ & $194,844,000.00$ & $\mathrm{Rp}$ & $136,844,000.00$ \\
\hline 2 & & Rp $1,583,964,000.00$ & $\mathrm{Rp}$ & $21,192,000.00$ & $\mathrm{Rp}$ & $1,605,156,000.00$ & $\mathrm{Rp}$ & $1,800,000,000.00$ & $\mathrm{Rp}$ & $194,844,000.00$ & $\mathrm{Rp}$ & $331,688,000.00$ \\
\hline 3 & & Rp $1,583,964,000.00$ & $\mathrm{Rp}$ & $21,192,000.00$ & $\mathrm{Rp}$ & $1,605,156,000.00$ & Rp & $1,800,000,000.00$ & $\mathrm{Rp}$ & $194,844,000.00$ & $\mathrm{Rp}$ & $526,532,000.00$ \\
\hline \multirow{2}{*}{$\mathrm{PPB}=$} & 0.30 & tahun & & & & & & & & & & \\
\hline & 3.572088 & bulan & & 3 bulan 17 hari & & & & & & & & \\
\hline
\end{tabular}

Tabel 7. Payback period alternatif beli motor bekas

\begin{tabular}{|c|c|c|c|c|c|c|c|c|c|c|c|}
\hline Tahun & Investasi & Biaya Operasional & Maintenance & & Total Biaya & & Pendapatan & & benefit & & us Kas Masuk \\
\hline 0 & $\begin{array}{ll}\mathrm{Rp} & 50.000 .000,00\end{array}$ & & & $\mathrm{Rp}$ & $50.000 .000,00$ & & & & & $\mathrm{Rp}$ & $(50.000 .000,00)$ \\
\hline 1 & & $\begin{array}{ll}\mathrm{Rp} & 1.634 .364 .000,00 \\
\end{array}$ & $\begin{array}{|ll|}R p & 33.390 .000,00 \\
\end{array}$ & $\mathrm{Rp}$ & $1.667 .754 .000,00$ & $\mathrm{Rp}$ & $1.800 .000 .000,00$ & $\mathrm{Rp}$ & $132.246 .000,00$ & $\mathrm{Rp}$ & $82.246 .000,00$ \\
\hline 2 & & $\begin{array}{ll}\mathrm{Rp} & 1.634 .364 .000,00 \\
\end{array}$ & Rp $33.390 .000,00$ & $\mathrm{Rp}$ & $1.667 .754 .000,00$ & $\mathrm{Rp}$ & $1.800 .000 .000,00$ & $\mathrm{Rp}$ & $132.246 .000,00$ & $\mathrm{Rp}$ & $214.492 .000,00$ \\
\hline 3 & & $\begin{array}{ll}\mathrm{Rp} & 1.634 .364 .000,00 \\
\end{array}$ & $\begin{array}{|ll|}\mathrm{Rp} & 33.390 .000,00 \\
\end{array}$ & $\mathrm{Rp}$ & $1.667 .754 .000,00$ & $\mathrm{Rp}$ & $1.800 .000 .000,00$ & $\mathrm{Rp}$ & $132.246 .000,00$ & $\mathrm{Rp}$ & $346.738 .000,00$ \\
\hline \multirow{3}{*}{$\mathrm{PBP}=$} & 0,38 & tahun & & & & & & & & & \\
\hline & 4,536999 & bulan & & & & & & & & & \\
\hline & 4 bulan 16 hari & & & & & & & & & & \\
\hline
\end{tabular}

Metode analisis kelayakan investasi yang selanjutnya adalah metode Payback period (PBP), dimana PBP merupakan metode dengan menggunakan penilaian suatu investasi dengan dasar lamanya investasi tersebut dapat tertutup dengan aliran kas masuk yang ada pada suatu perusahaan. Suatu investasi dikatakan layak apabila besarnya PBP kurang dari umur ekonomisnya. Sedangkan untuk alternatif yang dipilih adalah alternatif yang memiliki nilai PBP terkecil.

Untuk perhitungan dengan menggunakan metode Payback period (PBP), faktor yang mempengaruhi adalah cash flow untuk 3 tahun pertama. Dari perhitungan yang dilakukan diperoleh nilai PBP untuk alternatif membeli mobil baru adalah sebesar 6 bulan 24 hari. Sedangkan nilai PBP untuk alternatif membeli mobil bekas adalah sebesar 3 bulan 17 hari. Sedangkan nilai PBP untuk alternatif membeli motor bekas adalah sebesar 4 bulan 16 hari.

Berdasarkan perhitungan diketahui bahwa nilai PBP yang terkecil adalah 3 bulan 17 hari. Hasil perhitungan tersebut menunjukkan bahwa untuk periode tiga tahun pertama, alternatif yang memberikan pengembalian terhadap modal investasi yang tercepat adalah alternatif membeli mobil bekas.

\subsection{Pengambilan Keputusan Penggunaan Moda Transportasi}

Dari hasil analisis kelayakan investasi didapat hasil bahwa pembelian mobil bekas merupakan alternative pilihan terbaik (berdasarkan metode net present value dan pay back period). Berikut merupakan perbandingan moda transportasi dari keadaan awal dan usulan berdasarkan Analisis kelayakan investasi menggunakan Decision Tree Method. 


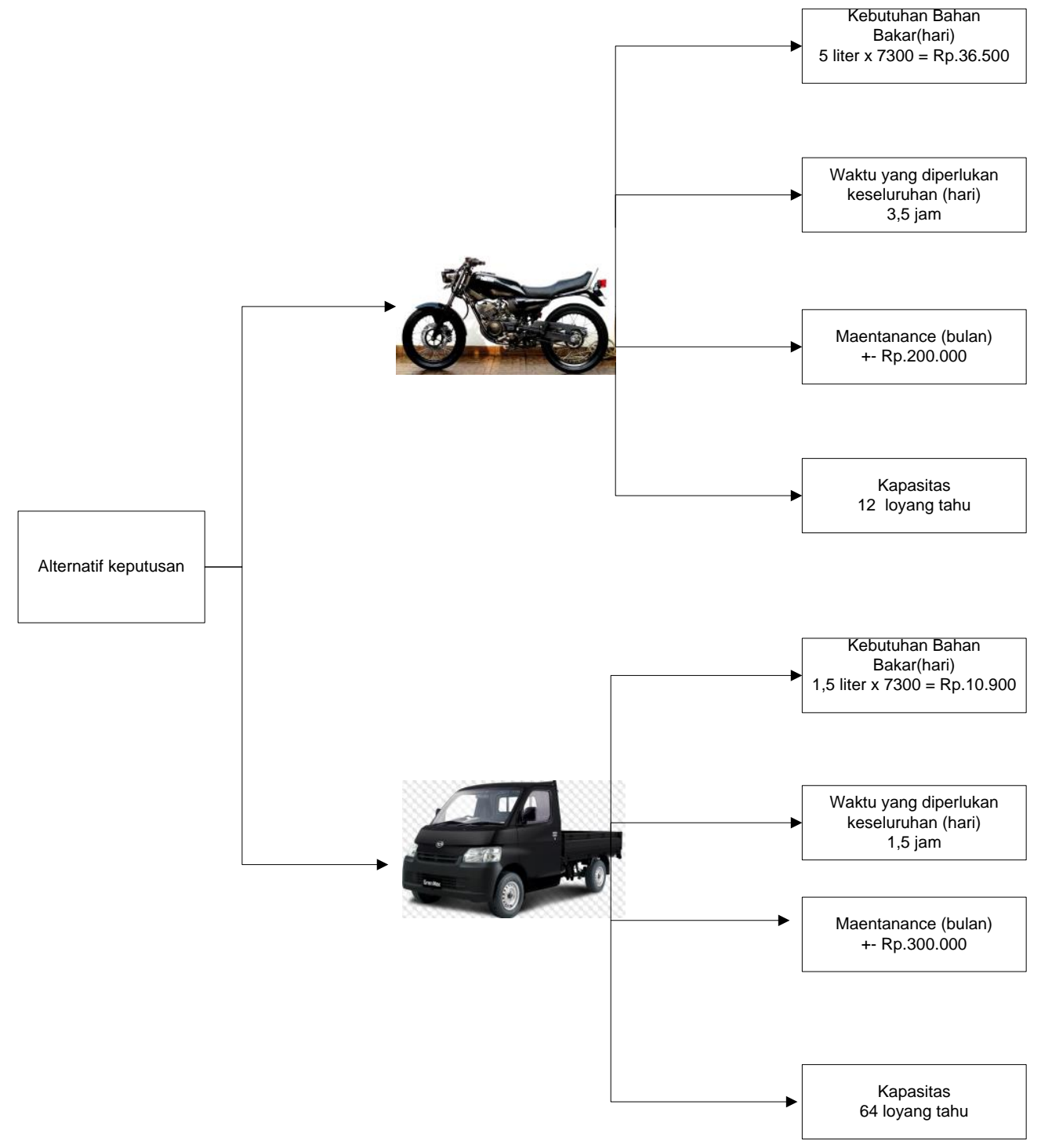

Gambar 4. Decision tree

Dari penjelasan diketahui bahwa penggunaan bahan bakar pada saat penggunaan motor sebesar 5 liter perhari, hal ini dikarenakan pada saat distribusi, armada yang digunakan harus bolak-balik akibat kapasitas yang hanya dapat.membawa tiga ember tahu sehingga diperlukan waktu selama tiga jam tiga puluh menit dalam mendistribusi tahu (total distribusi pagi dan sore), selain itu biaya perawatan relatif lebih murah daripada meggunakan mobil yaitu sebesar Rp.200.000/bulan, sedangkan dengan menggunakan moda transportasi sesuai dengan usulan maka terjadi peningkatan tingkat efisiensi mulai dari waktu, kapasitas yang dapat diangku yaitu sebanyak enam belas ember sekali jalan, dan biaya bahan bakar akibat tidak perlunya armada distribusi bolak-balik (sekali jalan). Maka dari itu pemilihan alternatif penggunaan mobil merupakan pilihan terbaik dalam masalah ini.

Selain dengan investasi mobil, alternatif yang dapat dipertimbangkan pula adalah dengan investasi sepeda motor baru. Untuk menyamai kapasitas angkut mobil, sepeda motor yang perlu diinvestasi adalah sebanyak 5 buah sepeda motor. Harga sepeda motor baru adalah sekitar Rp. 14.000.000,00. Jika diperlukan sepeda motor sebanyak 5 buah maka biaya investasi yang perlu dikeluarkan perusahaan adalah sebesar Rp. 70.000.000,00. Investasi tersebut nilainya lebih besar jika dibandingkan dengan investasi mobil bekas, sehingga sudah dapat dipastikan bahwa investasi mobil bekas lebih baik jika dibandingkan dengan investasi sepeda motor baru. Sedangkan alternatif lain yang dapat dipertimbangkan adalah investasi sepeda motor bekas. 
Harga sebuah motor bekas adalah sekitar Rp. 10.000.000,00, jika diperlukan sepeda motor sebanyak 5 buah maka biaya investasi yang dikeluarkan perusahaan adalah sebesar Rp. 50.000.000,00. Berdasarkan perhitungan dengan metode payback period, diketahui bahwa waktu kembali investasi yang dikeluarkan perusahaan adalah 4 bulan 16 hari, dengan pertimbangan biaya pengeluaran tambahan adalah biaya tenaga kerja sebesar Rp. 4.200.000,00 per bulan dan biaya maintenance untuk 5 sepeda motor meningkat sebesar Rp. 1.016.500,00,00. Dan berdasarkan perhitungan dengan mengunakan metode NPV, diketahui bahwa hasil yang diperoleh adalah Rp. 278.876.228,00. Dan hasil tersebut lebih kecil jika dibandingkan dengan investasi mobil.

Berdasarkan perbandingan alternatif sepeda motor dengan mobil, diketahui bahwa alternatif terbaik adalah investasi mobil bekas, dengan nilai payback period adalah sebesar 3 bulan 17 hari.

\section{Simpulan dan Saran}

Berdasarkan masalah yang terjadi pada UKM tersebut diperlukannya suatu pergantian armada distribusi akibat ketidakoptimalan armada yang ada baik dari segi kapasitas, waktu dan biaya. Dengan menggunakan analisis kelayakan investasi yaitu dengan net present value dan pay back period maka dipilih alternatif membeli mobil bekas yang dapat memberikan dampak secara langsung baik dari segi kapasitas, penggunaan bahan bakar, dan waktu yang dibutuhkan dalam aktivitas distribusi. Penelitian ini diharapkan dapat menjadi bahan pertimbangan pengambil keputusan dalam menyelesaikan masalah transportasi. Selain itu penelitian ini juga dapat dijadikan sebagai pembanding dalam menyelesaikan masalah yang serupa.

\section{Daftar Pustaka}

Ballou, H, R. 2004. Bussiness Logistics Management. Prentice-Hall: International, United States.

Chandra, A. 2013. Analisis Kinerja Distribusi Logistik pada Pasokan Barang dari Pusat Distribusi ke Gerai Indomaret di Kota Semarang. Skripsi. Fakultas Ekonomi dan Bisnis. Universitas Diponegoro.

Ghiani, G., Laporte, G., \& Musmanno, R. (2004). Introduction to Logistics Systems Planning and Control. England: John Wiley.

Kristanto, T., Suryani, E. 2015. Analisis Penentuan Estimasi Biaya, Penjadwalan dan Pengelolaan Distribusi serta Dampak Penggunaan Teknologi Informasi terhadap Kinerja Logistik (Studi Kasus: PT. Sunan Inti Perkasa). Prosiding Seminar Nasional Manajemen Teknologi XXII. ISBN : 978-602-70604-1-8.

Mahmudah, N., Parkesit D, dkk. 2011. Pengembangan Metodologi Perencanaan Transportasi Barang Regional. Jurnal Transpotasi Forum Studi Transportasi Antar Perguruan Tinggi Vol 11, No 3.

Mirah, N, L, P. 2013. Studi Kelayakan Investasi dari Aspek Finansialuntuk Pendirian Naya Salon Denpasar. Jurnal ekonomi bisnis Vol 11, No 3.

Prastowo, H., Taruna, Resa. 2014. Perbandingan Kelayakan Pembelian dan Sewa Mobil untuk Kendaraan Operasional di PT Panarub Industry. SINERGI Vol. 18, No. 1.

Syahrani, H.A. Husainie. 2003. Analisis Kelayakan Finansial Pengusahaan Kebun Hutan Dengan Tanaman Buah Durian (Durio Zibethis Murr). Jurnal Ekonomi Pembangunan, Vol.8,No.2,137146

Utami, W, S. 2015. Percepatan Dwelling Time: Strategi Peningkatan Kinerja Perdagangan Internasional di Pelabuhan Tanjung Priok. Jurnal Unnes. ISSN 2252-6765. 